\title{
The Impact of Hotel Service Innovation on Guest's Perceived Value and Return Intention
}

\author{
Yasser Ibrahim, Tamer M. Abbas, and Nouran S. Fahmy
}

Faculty of Tourism and Hotel Management, Helwan University, Egypt

\begin{abstract}
In hospitality industry several elements could positively affect return intention, such as hotel service innovation and guest's perceived value. Hotel service innovation consists of in many forms such as innovative hotel types, customization of service, use of information technology, process innovation, marketing-focused innovation, brand differentiation and pricing innovation. Guest's perceived value is classified into: emotional value, social value, price value, and quality value. Using data gathered from in-house guests in a sample of five-star hotels, the current study investigated the impact of hotel service innovation on guest's perceived value and return intention. A survey questionnaire was adopted in this study. The questionnaire consisted of 79 items divided into nine groups as innovative hotel types (IHT), customization of service (CS), use of information technology (UIT), process innovation (POI), marketing-focused innovation (MFI), brand differentiation (BD), pricing innovation (PI), guest's perceived value (GPV), and return intention (RI). The hypothesized conceptual model was tested using structural equation modelling (SEM). Findings revealed that hotel service innovation through innovative hotel types, use of information technology, process innovation, marketing-focused innovation, brand differentiation, and pricing innovation significantly impact guest's perceived value. Also, guest's perceived value significantly impacts return intention. In addition, hotel service innovation through innovative hotel types significantly impact return intention.
\end{abstract}

Keywords: Service innovation, Perceived value, Return intention, Structural Equation Modelling (SEM).

\section{Introduction}

In hospitality industry several elements could positively affect return intention, such as hotel service innovation (Wang et al., 2013) and guest's perceived value (Mahmoud et al., 2018). Accordingly, many researchers 
(Hsu \& Fang, 2009; Kanten \& yaşlioğlu, 2012; Ordanini \& Parasuraman, 2011) discussed that service innovation affects perceived value through creating new ideas for services to access the value. Also, several authors (Dixon et al., 2009; Khuong \& Giang, 2014; Norazah \& Norbayah, 2015) pointed that service innovation positively impact on guest's return intention.

The concept of service innovation has been adopted to obtain guest's perceived value, customer satisfaction, increase willing to intention to return to the hotel and to increase the competitive advantage in a global and growing market (Beesley \& Davidson, 2013; Grobelna \& Marciszewska, 2013; Kallmuenzer, 2018; Lu \& Tseng, 2010; Wu et al., 2010; Zehrer et al., 2015). Previous studies that linked hotel service innovation, guest's perceived value and return intention were limited (Kessler et al., 2015; Luoh et al., 2014; Nieves et al., 2014; Nieves \& SegarraCiprés, 2015; Thomas \& Wood, 2014; Tigu et al., 2013). Moreover, previous studies about guest's perceived value was a very few, which ignores other important aspects (El-Adly \& Eid, 2015; Sweeney \& Soutar, 2001). Therefore, the main aim of the study is to investigate the impacts of service innovation factors on guests' perceived value and their return intention in a sample of international five-star hotels in Cairo.

\section{Ltteraturereview}

\section{Service innovation}

Service innovation strengthens the growth of the global economy (O'Cass et al., 2013). As that service innovation not only transacts with the company, but is influenced by the human factor and innovative culture and the integration of processes and tools that help the company to create a new innovation to achieve the needs and wants of customers and ultimately benefit the company (Nagy, 2013). Toivonen and Tuominen (2009, p.893) defined service innovation as "a new service or such a renewal of an existing service which is put into practice and which provides benefit to the organization that has developed it; the benefit usually derives from the added value that the renewal provides the customers. In addition, to be an innovation the renewal must be new not only to its developer, but in a broader context". 


\section{The Impact of Hotel Service Innovation on Guest's Perceived Value and Return Intention}

Service innovation is the best way to know the needs and thus increases the likelihood of market success (Lusch et al., 2007). Also, it increases production, reducing costs, increases quality, increases customer satisfaction and availability, and makes customers feel comfortable (Abdallah \& Phan, 2007; Dixon et al., 2009); provides for competitive advantage (Hogan et al., 2011). Service innovation is a central theme of hospitality industry and researches academic about return intention.

\section{Guest's perceived value}

El-Adly (2019, p.2) defined the value as "All factors, qualitative and quantitative, subjective and objective, that make up the complete consumption experience". Also, Forozia et al. (2013) mentioned that the perceived value is the feature that customers receive against the total costs they repay thus the perceived value measure by time and price together through the benefit resulting from the trade-off between benefits and costs (Kotler, 2003; Parasuraman et al., 1988). Moreover, the perceived value is a criterion for the development of management strategies to communicate and provide value to the customer (Kotler \& Keller, 2011). Also, Stollery and Jun (2017) added that the researchers used the concept of perceived value to understand the purchasing behavior of customers when deciding. As for the guest, they used the perceived value to know the alternatives offered by the market rather than rely on quality (Petrick, 2002).

In addition, Chiang and Lee (2013) noted that perceived value is a factor which has a great effect on the customer's decisions making process of both hotel choice and booking intention (Chiang \& Jang, 2007). Also, perceived value of the customer plays an important role in determining customer satisfaction, decision making and purchase behaviours (Chen, 2012). Wherefore, guest's perceived value is an important theme of hotels about return intention.

\section{Return intention}

Hanai et al. (2008) mentioned that in the light of the competition between different companies, there are many choices available to customers, therefore the company must take many steps to attract customers return again in addition to attracting new customers. Also, Razak et al. (2014, p. 578) 
defined return intentions as "the individual's judgment about buying again a designated service from the same company."

Whereas Khuong and Giang (2014) pointed out that one of the factors that successful companies are interested in is maintaining their customers and increasing their desire to return. In addition, several researchers (Barros et al., 2010; Kozak, 2001; Kozak \& Rimmington, 2000; Woodside \& MacDonald, 1994) identified that there are several factors affecting the desire to repetition of the visit, which is the reputation or quality of services provided. Also, several authors (Alegre \& Cladera, 2009; Barros \& Assaf, 2012) explained that the intention to return by customers is affected by the number of times the previous visits or comfort, and the probability of return is repeated infrequent customers and therefore should be retained because the cost is much less than trying to attract new customers (Um et al., 2006).

\section{The Research Hypotheses}

\section{Hotel Service Innovation and Guest's Perceived Value}

Mahmoud et al. (2018) indicated that there is a correlation between service innovations and perceived value for guests as service innovation is as an activity affecting the perceived value to guests. Moreover, the services industry covers a large scale of activities, and there are many studies that support the types that affect innovation services, namely innovative hotel types, customization of service, use of information technology, process innovation, marketing-focused innovation, brand differentiation and pricing innovation (Khuong \& Giang, 2014).

\section{Relationship between innovative hotel types and perceived value}

Hsu and Lee (2009) identified that green hotels are one of the forms of service innovation in hotel. These hotels cater for and provide forms of perceived value to customers, which include: emotional value, social value, the value of price and value quality (Teng et al., 2018). Also, Chahal and Kumari (2012) indicated that successful health care services serve to satisfy the perceived values of customers from emotional value through selfsatisfaction and social value through social interaction and price value through treatment and quality value through efficiency. Thus, first hypothesis is suggested: Value.

H1: Innovative Hotel Types positively influences Guest's Perceived 
Relationship between customization of service and guest's perceived value

Benedict et al. (2004) also mentioned that customization of service is of great importance as it increases the value to customers. As the customization positively affects the value because this customization in the service makes it perceived as having a high value (Scholl-Grissemann \& Schnurr, 2016). Hence, this study hypothesizes that:

H2: Customization of Service positively influences Guest's Perceived Value.

\section{Relationship between use of information technology and guest's perceived value}

Komulainen et al. (2004) stated that use of information technology affects the perceived value of the guest, although the customer perceived value is largely customer expected value, customers still distinguish certain elements of value that they look for it. Also, increasing the use of technology innovations increases the perceived value of customers (Dixon et al., 2009). Thus, this study hypothesizes that:

H3: Use of Information Technology positively influences Guest's Perceived Value.

\section{Relationship between process of innovation and guest's perceived value}

Mahmoud et al. (2018) stated that process innovation positively influences on the guest's perceived value. Moreover, Anthonisz (2014) pointed out that the process of innovation is to append new things to increase the value offered to customers. Therefore, fourth hypothesis is suggested:

H4: Process Innovation positively influences Guest's Perceived Value.

\section{Relationship between marketing-focused innovation and guest's perceived value}

Chuah et al. (2016) stated that the marketing innovation improve customers' quality and price perceptions (functional and monetary values) that will in turn, enhance perceived emotional value. Moreover, marketing innovation positively impacts to guest's perceived value (Khuong \& Giang, 2014). Thus, helps to increase the number of customers. Also, marketing innovation 
contributes to achieving the perceived value through increasing competitive advantage (Chuah et al., 2016). Hence, the following hypothesis can be formulated:

H5: Marketing-Focused Innovation positively influences Guest's Perceived Value

\section{Relationship between brand differentiation and guest's perceived value}

Kim et al. (2015) indicated that there are many benefits of the brand that contribute to increase the perceived value to customers. As the brand that provides the needs and desires of customers provides price value and quality value. Thus, the brand innovation implementation has mediating influence on customer value. The brand innovation implementation significantly, directly and positively affects the customer value. Hence, this study hypothesizes that:

H6: Brand Differentiation positively influences Guest's Perceived Value

\section{Relationship between pricing innovation and guest's perceived value}

Shanahan and Hyman (2007) explained that the price can realize the perceived value of the service when the price of services appropriates to the value obtained and thus the customer has been convinced that what he deserves what he got. In addition, pricing innovation affects the perceived value of the guest (Khuong \& Giang, 2014). Thus, this study hypothesizes that:

H7: Pricing Innovation positively influences Guest's Perceived Value

\section{Guest's Perceived Value and Return Intention}

Ryu et al. (2010) indicated that recent studies have proved that the behavioral intentions of customers are influenced by perceived value. Also, cronin et al. (2000) explained that the perceived value of customers is one of the best indicators of repurchase intention as it has a positive impact revisit intention (Lien et al., 2011; Rasoolimanesh et al., 2016) because customers are evaluating the intentions to repurchase based on the value obtained previously (Olaru, 2008). Therefore, this study hypothesizes that:

H8: Guest's Perceived Value positively influences Return Intention 


\section{Hotel Service Innovation and Return Intention Relationship between innovative hotel types return intention}

Wang et al. (2013) noted that the innovative hotel types offer high quality and distinctive services (Goh, 2015) and offered a comfortable atmosphere and a positive feeling of customers and satisfy their desires. All these features make customers repeat visit these hotels more than once (Norazah \& Norbayah, 2015). Thus, this study hypothesizes that: Intention

H9: Innovative Hotel Types positively influences Guest's Return

\section{Relationship between use of information technology and return intention}

In the hospitality industry, technological innovation is one of the things that contributes to increasing in the frequency of a customer's desire to return to visit again (Dixon et al., 2009). Therefore, this study hypothesizes that:

H10: Use of Information Technology positively influences Guest's Return Intention

\section{Relationship between marketing-focused innovation and return intention}

Marketing-focused innovation has a positive impact on the intention of guests to return once again (Khuong \& Giang, 2014). Thus, this study hypothesizes that:

H11: Marketing-focused Innovation positively influences Guest's Return Intention

\section{Relationship between brand differentiation and return intention}

Palacios-Marques et al. (2016) explained that the company's brand of assets that contribute to customer retention. Also increasing the brand in the minds of customers will increase their intention to repeat the visit (Zhou, 2011). Therefore, this study hypothesizes that:

H12: Brand Differentiation positively influences Guest's Return Intention 


\section{Ibrahim, Y $\quad$ M. Abbas, $T \quad$ S. Fahmy, N}

\section{Relationship between pricing innovation and return intention}

Lockyer (2005) identified that the price is one of the most important elements of the hotel's test and therefore the pricing innovation is very important in influencing the intention of returning guests to hotels again (Khuong \& Giang, 2014). Hence, this study hypothesizes that:

H13: Pricing Innovation positively influences Guest's Return Intention

The given hypotheses are expressed in the proposed research model in Figure

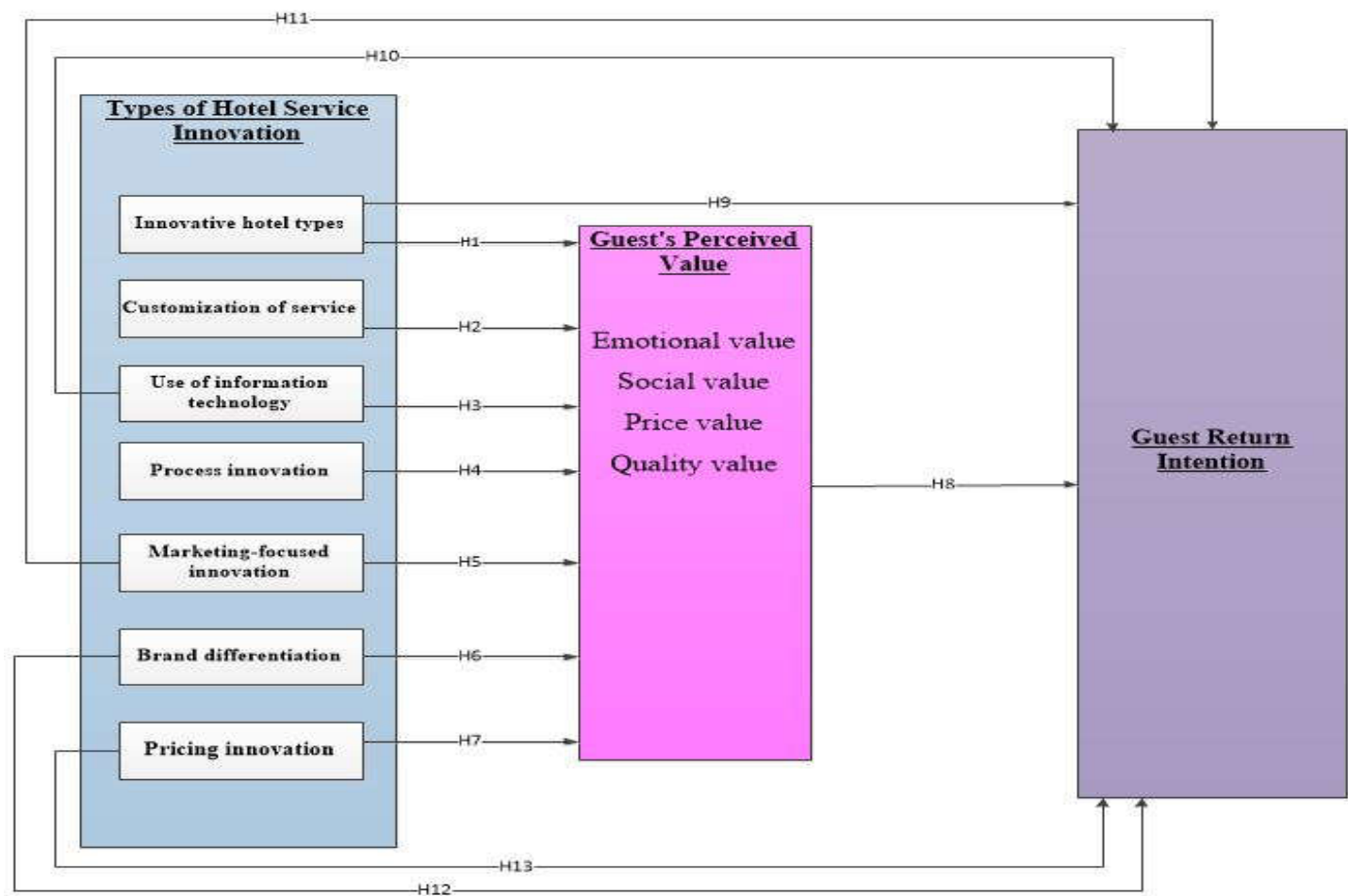

1Fig. 1: The proposed conceptual research model

\section{Methodology}

A survey questionnaire was used to collect the required data needed to test the research hypotheses against the proposed model (Figure 1). The target population for this study was all guest in five-star hotels in Cairo. A total of 280 questionnaires were randomly distributed to a sample of guests who stayed in the hotels were surveyed. Among the questionnaires returned, 220 were useable ones, representing a response rate of 78.6.\% 


\section{The Impact of Hotel Service Innovation on Guest's Perceived Value and Return Intention}

\section{Structural Equation Modelling (SEM)}

Structural Equation Modeling (SEM) is a multivariate statistical framework used to analyze structural relationships. SEM is a general framework that includes the simultaneous solution of linear equation systems and includes other techniques such as regression, factor analysis, path analysis and modeling of the underlying growth curve (Elston et al., 2012). This method is preferred by the researcher because it estimates the multiple and interrelated dependence in a single analysis. In this analysis, two types of variables were used; independent and dependent variables (Hair et al., 2010). SEM includes multiple ways of analysis of which confirmatory factor analysis was adopted. A two-step approach for structural equation modeling (SEM) was utilized.

The use of SEM increases the statistical efficiency of the results of this study in several ways. Firstly, it allows the analyses of multiple structural relationships at the same time, which results in more exact modelling than the utilization of the SPSS method (Hair et al., 2006). Secondly, the direct and indirect effects of all the independent variables on guest's perceived value and return intention can be assessed easily at once. Finally, the SEM technique reduces the measurement error problem related to the test of the mediating effects. This is because SEM method provides explicit estimates of the measurement errors and consequently considered to be a more superior method (Tarka, 2018).

In the first step, a confirmatory factor analysis (CFA) was used to test the measurement model. CFA is a special form to verify the validity of the data and also considered a very sophisticated statistical procedure for testing complex theoretical models of data (Prudon, 2015). It is used to test whether measures of a construct are consistent with a researcher's understanding of the nature of that constructing. As such, the objective of confirmatory factor analysis is to test whether the data fit a hypothesized measurement model. In the second step, goodness-of-fit measures were utilized to assess the structural fit of the hypothesized model. Theory suggests that if the chisquare $\left(x^{2}\right)$ is not significant the model is regarded as acceptable, nevertheless many disregards this since chi-square $\left(x^{2}\right)$ is often reported as significant mainly due to sample size restrictions and its sensitivity to the likelihood test ratio. 
Analysis of Moment Structures (AMOS), which is a software program that is a part of the SPSS software suite, was used for CFA and SEM. Composite reliability and Cronbach's alpha for each latent variable were used to test the construct reliability, and average variance extracted was used to test the construct convergent and discriminant validity (Arbuckle, 2011).

\section{Results}

\section{Structural Equation Modeling}

\section{The Confirmatory factor analysis (CFA)}

Confirmatory factor analysis (CFA) was used to measure the reliability and validity of the hotel service innovation, guest's perceived value and return intention scales. The initial model was not a satisfactory fit and so some modification indices were suggested to improve the model fit. More specifically, some items were removed from control scale. As a result, a good model fit was achieved for the measurement model: $(X 2=278.803, \mathrm{df}=129$, $\mathrm{p}>0.001)(\mathrm{X} 2 / \mathrm{df}=2.16$, comparative fit index $(\mathrm{CFI})=.979$, goodness-of-fit index GFI) $=.929$, Tucker-Lewis index (TLI) were greater than the recommended level of 0.90 (Hu \& Bentler, 1999; Byrne, 2010)., root mean square error of approximation (RMSEA) was lower than the cutoff value of 0.05 (Arbuckle, 2011).

The results of CFA (see Table 1) shows that the lowest value of CR and Cronbach's a for all of the constructs was 0.71 , which exceeded the minimum acceptable value of 0.70 , indicating a good reliability level. Additionally, the values of AVE for all constructs exceeded the minimum acceptable value of 0.50 indicating good convergent validity (Hair, et al., 2010). Furthermore, the results of CFA (see Table 2) show that the AVE of each construct was greater than the squared correlation for each pair of constructs, indicating good discriminant validity (Hair, et al., 2010). 
Table 1: Hotel Service Innovation, Perceived Value and Return Intention

Confirmatory Factor Analysis Results

\begin{tabular}{|c|c|c|c|c|c|c|c|}
\hline Constructs & $\begin{array}{l}\text { Factor } \\
\text { loadings }\end{array}$ & t-Value & $\mathbf{P}$ & B & CR & $\alpha$ & AVE \\
\hline $\begin{array}{l}\text { Customization of } \\
\text { service (CS) }\end{array}$ & & & & & .746 & .712 & .573 \\
\hline CS 1 & 1.000 & & & .551 & & & \\
\hline $\mathrm{CS} 2$ & 1.073 & 3.847 & $* * *$ & .595 & & & \\
\hline $\begin{array}{l}\text { Use of information } \\
\text { technology (UIT) }\end{array}$ & & & & & .701 & .796 & .500 \\
\hline UIT1 & 1.000 & & & .517 & & & \\
\hline UIT2 & .640 & 4.687 & $* * *$ & .485 & & & \\
\hline UIT3 & .805 & 4.854 & $* * *$ & .498 & & & \\
\hline $\begin{array}{l}\text { process innovation } \\
(\mathrm{POI})\end{array}$ & & & & & .868 & .847 & .689 \\
\hline POI 1 & 1.000 & & & .752 & & & \\
\hline POI 2 & 1.090 & 8.856 & $* * *$ & .754 & & & \\
\hline POI 3 & .701 & 5.793 & $* * *$ & .552 & & & \\
\hline $\begin{array}{l}\text { marketing-focused } \\
\text { innovation (MFI) }\end{array}$ & & & & & .832 & .813 & .619 \\
\hline MFI 1 & 1.000 & & & .518 & & & \\
\hline MFI 2 & 1.810 & 5.378 & $* * *$ & .756 & & & \\
\hline MFI 3 & 1.335 & 5.350 & $* * *$ & .583 & & & \\
\hline $\begin{array}{l}\text { brand } \\
\text { differentation (BD) }\end{array}$ & & & & & .847 & .837 & .649 \\
\hline BD 1 & 1.000 & & & .679 & & & \\
\hline BD 2 & .918 & 8.090 & $* * *$ & .710 & & & \\
\hline BD 3 & .707 & 5.570 & $* * *$ & .550 & & & \\
\hline $\begin{array}{l}\text { pricing innovation } \\
\text { (PI) }\end{array}$ & & & & & .843 & .833 & .655 \\
\hline PI 1 & 1.000 & & & .795 & & & \\
\hline PI 2 & .853 & 7.989 & $* * *$ & .720 & & & \\
\hline PI 3 & .435 & 4.494 & $* * *$ & .450 & & & \\
\hline $\begin{array}{l}\text { perceived value } \\
\text { (GPV) }\end{array}$ & & & & & .815 & .805 & .672 \\
\hline GPV 1 & 1.000 & & & .655 & & & \\
\hline GPV 2 & 1.053 & 7.322 & $* * *$ & .734 & & & \\
\hline GPV 3 & 1.125 & 8.030 & $* * *$ & .628 & & & \\
\hline $\begin{array}{l}\text { return intentions } \\
\text { (RI) }\end{array}$ & & & & & 638 & .828 & .501 \\
\hline RI 1 & 1.000 & & & .481 & & & \\
\hline RI 2 & 1.136 & 4.524 & $* * *$ & .621 & & & \\
\hline RI 3 & .817 & 3.779 & $* * *$ & .437 & & & \\
\hline RI 4 & 1.064 & 4.199 & $* * *$ & .513 & & & \\
\hline RI 5 & 1.001 & 4.173 & $* * *$ & .496 & & & \\
\hline RI 6 & .614 & 3.164 & .002 & .486 & & & \\
\hline RI 7 & .791 & 3.603 & $* * *$ & .474 & & & \\
\hline
\end{tabular}

Note: All factor loadings were significant at $\leq .001 ; \mathrm{CR}=$ Composite reliability; $\alpha=$ Alpha reliability;

$\mathrm{AVE}=$ average variance extracted. 


\section{Ibrahim, Y $\quad$ M. Abbas, $T \quad$ S. Fahmy, N}

Table 2: Validity Assessment Criteria and Correlation Matrix

\begin{tabular}{|l|l|l|l|l|l|l|l|l|}
\hline Construct & CS & UIT & POI & MKI & BD & PI & GPV & RI \\
\hline CS & $\mathbf{. 5 7 3}$ & & & & & & & \\
\hline UIT & .457 & $\mathbf{. 5 0 0}$ & & & & & & \\
\hline POI & .355 & .390 & $\mathbf{. 6 8 9}$ & & & & & \\
\hline MKI & .171 & .298 & .213 & $\mathbf{. 6 1 9}$ & & & & \\
\hline BD & .351 & .479 & .289 & .008 & $\mathbf{. 6 4 9}$ & & & \\
\hline PI & .254 & .353 & .321 & .141 & .236 & $\mathbf{. 6 5 5}$ & & \\
\hline GPV & .297 & .480 & .378 & .024 & .416 & .266 & $\mathbf{. 4 6 4}$ & \\
\hline RI & .089 & .181 & .084 & .083 & .092 & .155 & .181 & $\mathbf{. 5 0 1}$ \\
\hline
\end{tabular}

Note: Diagonal entries (in bold) are the square root of AVE; sub-diagonal entries are the latent construct inter-correlations.

\section{Study Structural Model}

The purpose of this section is to empirically examine and test the hypothesized relations among the study variables presented in using structural equation modeling (SEM). Upon achieving a good measurement model fitness with valid and reliable constructs. The model can now be tested utilizing SEM for hypotheses testing. Current study proposed a structural model which is consisted of nine major latent constructs, of which seven are exogenous (innovative hotel types, customization of service, use of information technology, process innovation, marketing-focused innovation, brand differentiation and pricing innovation) and two are endogenous (guest's perceived value and return intentions). Figure (2) presents the proposed structural model and the initial proposed relationships among constructs.

The overall model fitness of the proposed structural model was examined. After modifying model fit indices, the modified alternative model indicated an excellent fit of the model to the observed data, see (table 3) below. $(\mathrm{X} 2=278.803, \mathrm{df}=129, \mathrm{p}>0.001)(\mathrm{X} 2 / \mathrm{df}=2.16$, comparative fit index $(\mathrm{CFI})=$ .979 , goodness-of-fit index GFI) $=.929$, Tucker-Lewis index (TLI) were greater than the recommended level of 0.90 (Hu \& Bentler, 1999; Byrne, 2010)., root mean square error of approximation (RMSEA) was lower than the cutoff value of 0.05 (Arbuckle, 2011). Table (3) depicts the overall fitness of the modified study structural model compared to cut-off values. The analysis of SEM on the modified model has generated results which are illustrated in table (3) below. 


\section{The Impact of Hotel Service Innovation on Guest's Perceived Value and Return Intention}

Table 3: Overall fitness of Modified Study Structural Model Compared to cut-off

\begin{tabular}{|l|l|l|l|l|l|l|}
\hline \multirow{2}{*}{ Model } & \multicolumn{1}{|l|}{ Goodness of fit results } \\
\cline { 2 - 7 } & \multicolumn{1}{|c|}{$\boldsymbol{\chi 2}$} & $\boldsymbol{\chi 2} \mathbf{2} \mathbf{d f}$ & $\mathbf{P}$ & GFI & CFI & RMSEA \\
\hline $\begin{array}{l}\text { Modified structural } \\
\text { model }\end{array}$ & 278.803 & 2.16 & .000 & .929 & .979 & .047 \\
\hline $\begin{array}{l}\text { Cut-off values } \\
\text { The lower } \\
\text { the better }\end{array}$ & & & $\mathbf{> 0 . 9 0}$ & $>\mathbf{0 . 9 0}$ & $\begin{array}{l}<\mathbf{0 . 0 5} \text { with CFI } \\
\text { of } 0.90 \text { or higher }\end{array}$ \\
\hline
\end{tabular}

Note: CFI-comparative fit index- GFI-goodness-of-fit index-; RMSEA - Root Mean Square of

Approximation (model fit indices indicate good fit to the data)

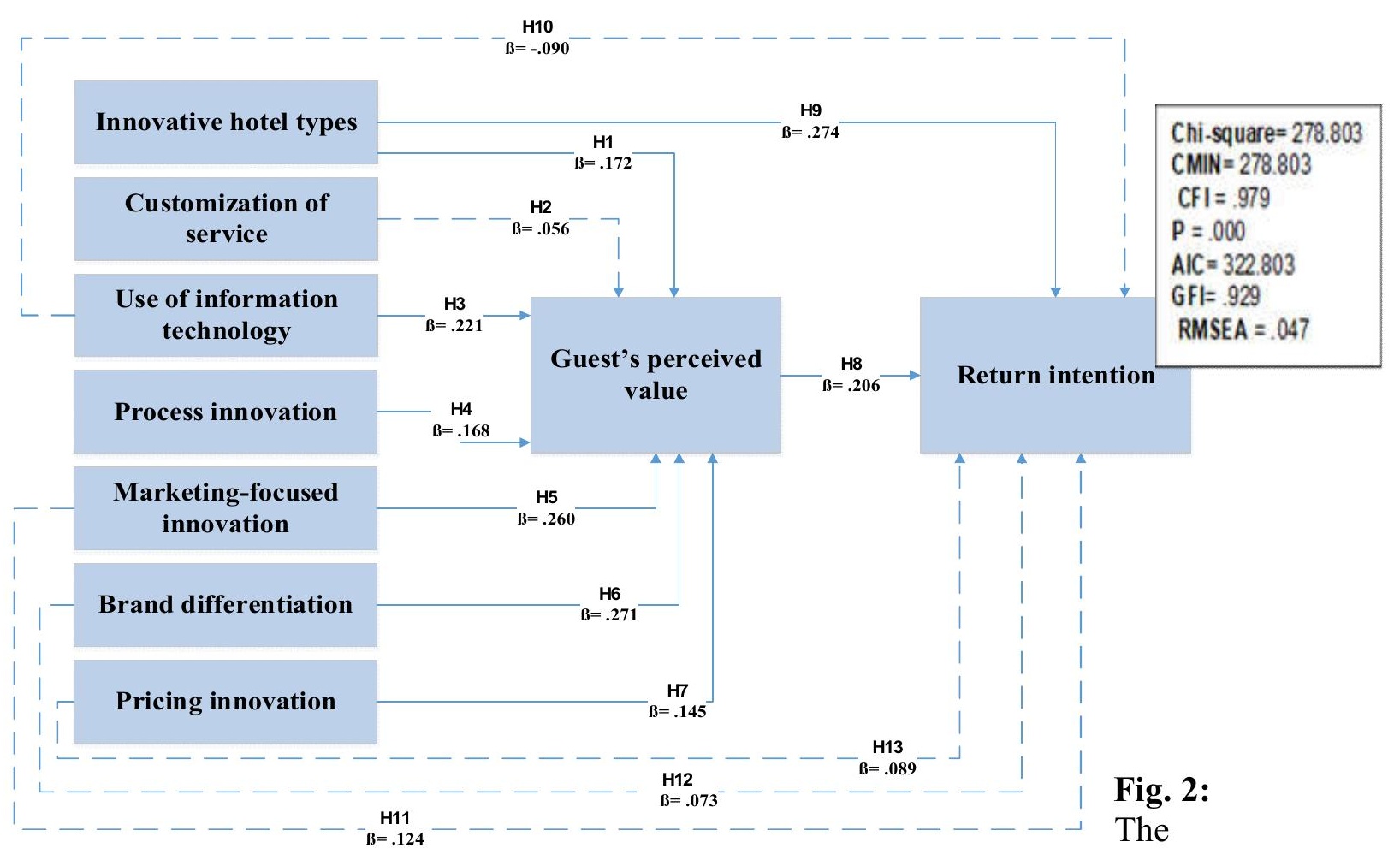

Fig. 2: The Modified Final Structural Model of the Study

\section{Hypotheses Testing}

Table (4) below presents standardized coefficient $(\beta)$ to test the postulated direct paths between study independent, moderating, and dependent variables. Return intention was used as dependent variables, guest's perceived value was used as moderating variables, and hotel service innovation included innovative hotel types, customization of service, use of information technology, process innovation, marketing-focused innovation, brand 


\section{Ibrahim, Y $\quad$ M. Abbas, $T \quad$ S. Fahmy, N}

differentiation and pricing innovation. Results of hypotheses testing are discussed in the following sections.

Table 4: Standardized parameter estimates of the structural model

\begin{tabular}{|c|c|c|c|c|c|}
\hline Hypotheses & Path & $\begin{array}{c}\text { Beta } \\
\text { coefficients } \\
(\text { (B) }\end{array}$ & t-values & $\mathbf{p}$ & Results \\
\hline $\mathrm{H} 1$ & Innovative hotel types & .172 & 2.702 & .007 & Supported \\
\hline $\mathrm{H} 2$ & Customization of service & .056 & .889 & .374 & Rejected \\
\hline $\mathrm{H} 3$ & $\begin{array}{l}\text { Use of information technology } \\
\text { value }\end{array}$ & .221 & 3.668 & $* * *$ & Supported \\
\hline $\mathrm{H} 4$ & Process innovation & .168 & 2.882 & .004 & Supported \\
\hline H5 & $\begin{array}{l}\text { Marketing-focused innovation } \\
\text { value }\end{array}$ & .260 & 4.763 & $* * *$ & Supported \\
\hline H6 & Brand differentiation stest's perceived value & .271 & 4.346 & $* * *$ & Supported \\
\hline $\mathrm{H} 7$ & Pricing innovation $\quad$ gtest's perceived value & .145 & 2.518 & .012 & Supported \\
\hline $\mathrm{H} 8$ & Guest's perceived value & .206 & 2.536 & .011 & Supported \\
\hline H9 & Innovative hotel types $\rightarrow$ raturn intention & .274 & 3.821 & $* * *$ & Supported \\
\hline $\mathrm{H} 10$ & Use of information technology raturn intention & -.090 & -1.357 & .175 & Rejected \\
\hline H11 & Marketing-focused innovation & .124 & 1.886 & .059 & Rejected \\
\hline $\mathrm{H} 12$ & Brand differentiation & .073 & 1.018 & .309 & Rejected \\
\hline H13 & Pricing innovation Tturn intention & .089 & 1.377 & .169 & Rejected \\
\hline
\end{tabular}

Absolute $t$-value $>1.96, \mathrm{p}<0.05 ; * *$ Absolute $t$-value $>2.58, \mathrm{p}<0.01 ; * * *$ Absolute $t$-value $>$

$4.76, \mathrm{p}<0.001$.

\section{The Association between Innovative hotel types and guest's perceived value}

The paths that connects innovative hotel types with guest's perceived value yields a significant coefficient value of $\beta=.172$ ( $\mathrm{P}$ significant at 0.007 ). Hence a significant positive coefficient for innovative hotel types, suggesting that innovative hotel types is positively associated with guest's perceived value, as predicted, thereby confirming H1. In other words, the result supports H1.

\section{The Association between customization of service and guest's perceived value}

It can be seen from the modified final study structural model that a no direct relationship between customization of service and guest's perceived value was found. Initial study model revealed a weak positive relation between the two constructs; however, the initial model didn't yield a good fit to the data, the model fit indices suggested removing the direct paths between customization of service and guest's perceived value, upon removing this 
path, the final modified model showed an excellent fit. So, it was found that customization of service is not directly associated with guest's perceived value, thus rejecting the $\mathrm{H} 2$.

\section{The Association between use of information technology and guest's perceived value}

The paths that connects use of information technology with guest's perceived value yields a significant coefficient value of $\beta=.221$ (P significant at 0.001 ). Hence a significant positive coefficient for use of information technology, suggesting that use of information technology is positively associated with guest's perceived value, as predicted, thereby confirming H3. In other words, the result supports $\mathrm{H} 3$.

\section{The Association between process innovation and guest's perceived value}

The paths that connects process innovation with guest's perceived value yields a significant coefficient value of $\beta=.168$ (P significant at 0.004). Hence a significant positive coefficient for process innovation, suggesting that process innovation is positively associated with guest's perceived value, as predicted, thereby confirming H4. In other words, the result supports H4.

\section{The Association between marketing-focused innovation and guest's perceived value}

The paths that connects marketing-focused innovation with guest's perceived value yields a significant coefficient value of $\beta=.260$ (P significant at 0.001). Hence a significant positive coefficient for marketing-focused innovation, suggesting that marketing-focused innovation is positively associated with guest's perceived value, as predicted, thereby confirming H5. In other words, the result supports $\mathrm{H} 5$.

\section{The Association between brand differentiation and guest's perceived value}

The paths that connects brand differentiation with guest's perceived value yields a significant coefficient value of $\beta=.271$ ( $\mathrm{P}$ significant at 0.001 ). Hence a significant positive coefficient for brand differentiation, suggesting that brand differentiation is positively associated with guest's perceived 
value, as predicted, thereby confirming H6. In other words, the result supports H6.

\section{The Association between pricing innovation and guest's perceived value}

The paths that connects pricing innovation with guest's perceived value yields a significant coefficient value of $\beta=.145$ ( $P$ significant at 0.012 ). Hence a significant positive coefficient for pricing innovation, suggesting that pricing innovation is positively associated with guest's perceived value, as predicted, thereby confirming H7. In other words, the result supports H7.

\section{The Association between guest's perceived value and return intention}

The paths that connects guest's perceived value with return intention yields a significant coefficient value of $\beta=.206$ ( $P$ significant at 0.011 ). Hence a significant positive coefficient for guest's perceived value, suggesting that guest's perceived value is positively associated with return intention, as predicted, thereby confirming H8. In other words, the result supports H8.

\section{The Association between Innovative hotel types and return intention}

The paths that connects innovative hotel types with return intention yields a significant coefficient value of $\beta=.274$ ( $P$ significant at 0.001 ). Hence a significant positive coefficient for innovative hotel types, suggesting that innovative hotel types is positively associated with return intention, as predicted, thereby confirming H9. In other words, the result supports H9.

\section{The Association between use of information technology and return intention}

It can be seen from the modified final study structural model that a no direct relationship between use of information technology and return intention was found. Initial study model revealed a weak positive relation between the two constructs; however, the initial model didn't yield a good fit to the data, the model fit indices suggested removing the direct paths between use of information technology and return intention, upon removing this path, the final modified model showed an excellent fit. So, it was found that use of information technology is not directly associated with return intention, thus rejecting the $\mathrm{H} 10$. 


\section{The Association between marketing-focused innovation and return intention}

It can be seen from the modified final study structural model that a no direct relationship between marketing-focused innovation and return intention was found. Initial study model revealed a weak positive relation between the two constructs; however, the initial model didn't yield a good fit to the data, the model fit indices suggested removing the direct paths between marketingfocused innovation and return intention, upon removing this path, the final modified model showed an excellent fit. So, it was found that marketingfocused innovation is not directly associated with return intention, thus rejecting the $\mathrm{H} 11$.

\section{The Association between brand differentiation and return intention}

It can be seen from the modified final study structural model that a no direct relationship between brand differentiation and return intention was found. Initial study model revealed a weak positive relation between the two constructs; however, the initial model didn't yield a good fit to the data, the model fit indices suggested removing the direct paths between brand differentiation and return intention, upon removing this path, the final modified model showed an excellent fit. So, it was found that brand differentiation is not directly associated with return intention, thus rejecting the H12.

\section{The Association between pricing innovation and return intention}

It can be seen from the modified final study structural model that a no direct relationship between pricing innovation and return intention was found. Initial study model revealed a weak positive relation between the two constructs; however, the initial model didn't yield a good fit to the data, the model fit indices suggested removing the direct paths between pricing innovation and return intention, upon removing this path, the final modified model showed an excellent fit. So, it was found that pricing innovation is not directly associated with return intention, thus rejecting the H13.

\section{Discussion and Implications}

The current study tested impact of hotel service innovation on guest's perceived value and return intention. The results showed that hotel service 
innovation had significant effect on guest's perceived value and return intention. These findings agree with all previous studies findings, as a direct significant path between innovative hotel types and guest's perceived value was identified $\beta=.172$, supporting that innovative hotel types positively influence guest's perceived value in hotels. These findings indicate the huge importance of boutique hotels, green hotels and healthcare hotels cater for and provide forms of perceived value to customers, which include: emotional value, social value, the value of price and value quality (Chahal \& Kumari, 2012; Hsu \& Lee, 2009; Teng et al., 2018). Therefore, five-star hotels should pay more attention to innovative hotel types due to benefits that achieve, as it increases market share, increases competitive advantages, increases production, increases quality, increases guest satisfaction and the desire to intention to return again. In addition, there is a direct significant path between use of information technology and guest's perceived value was identified $\beta=$ .221 , supporting that use of information technology positively influence guest's perceived value in hotels. These findings indicate the huge importance of use of information technology because it increases the perceived value of guests (Dixon et al., 2009; Komulainen et al., 2004). Thus, five-star hotels should pay extra care for new trends of use of information technology (e.g., using guest room lock access via guest's mobile phone and offers touch screen for guest use with all information about the city). Furthermore, there is a direct significant path between process innovation and guest's perceived value was identified $\beta=.168$, supporting that process innovation positively influence guest's perceived value in hotels. These findings indicate the huge importance of process innovation because it is to append new things to increase the value offered to guests (Anthonisz, 2014; Mahmoud et al., 2018). Therefore, five-star hotels should pay more attention to process innovation (e.g., offer new or improve ideas and services).

Moreover, there is a direct significant path between marketing-focused innovation and guest's perceived value was identified $\beta=260$, supporting that marketing-focused innovation positively influence guest's perceived value in hotels. These findings indicate the huge importance of marketingfocused innovation because it achieves the perceived value through increasing competitive advantage (Chuah et al., 2016; Khuong \& Giang, 2014). Thus, five-star hotels should pay more attention to the marketingfocused innovation (e.g., social media marketing, mobile marketing, loyalty programs, and discount cards). As well as, there is a direct significant path between brand differentiation and guest's perceived value was identified $\beta=$ .271 , supporting that brand differentiation positively influence guest's 


\section{The Impact of Hotel Service Innovation on Guest's Perceived Value and Return Intention}

perceived value in hotels. These findings indicate the huge importance of brand differentiation because it provides the needs and desires of customers provides price value and quality value (Kim et al., 2015). Thus, five-star hotels should pay extra care the brand differentiation. Also, there is a direct significant path between pricing innovation and guest's perceived value was identified $\beta=.145$, supporting that pricing innovation positively influence guest's perceived value in hotels. These findings indicate the huge importance of pricing innovation (Khuong \& Giang, 2014; Shanahan \& Hyman, 2007).

Therefore, five-star hotels should pay more attention to the pricing innovation because it can realize the perceived value of the service when the price of services appropriates to the value obtained and thus the customer has been convinced that what he deserves what he got.

In addition, there is a direct significant path between guest's perceived value and return intention was identified $\beta=.206$, supporting that guest's perceived value positively influence return intention in hotels. These findings indicate the huge importance of guest's perceived value because it is one of the best indicators of repurchase intention as it has a positive impact revisit intention (cronin et al., 2000; Lien et al., 2011; Rasoolimanesh et al., 2016; Ryu et al., 2010). Therefore, five-star hotels should seek to provide the perceived value to guests as a mean of influencing return intention. Finally, there is a direct significant path between innovative hotel types and return intention was identified $\beta=.274$, supporting that innovative hotel types positively influence return intention in hotels. These findings indicate the huge play an important role of innovative hotel types because it provides high quality and distinctive services to influence the client's intention to return again (Goh, 2015; Han ,2013; Wang et al., 2013).

\section{Limttaions and Future Research}

The study possesses some limitations; it examined the impact of hotel service innovation on guest's perceived value and return intention. In that sense, it is worthwhile for further studies to focus on different sectors within the hospitality industry (for instance, restaurants, bars, cruise ships, resorts, hostels, ...etc.). Furthermore, this study investigated the hotel service innovation using a sample of five-star hotels in Greater Cairo, Egypt. Thus, in the further studies, it is worthwhile to focus on hotel service innovation in 
other cities such as Sharm El-Sheikh or Luxor. in addition, the sample used for this study was a small proportion of the entire hotels' guests' population; thus, further researches with a bigger sample size would be required to ensure appropriate generalization of study findings. However, despite these limitations, this study has useful implications both for hospitality scholars and industry practitioners.

\section{References}

Abdallah, A. and Phan, C. (2007). The relationship between just-in-time production and human resource management, and their impact on competitive performance. Yokohama Business Review, 28 (2), 27-57.

Alegre, J. and Cladera, M. (2009). Analysing the effect of satisfaction and previous visits on tourist intentions to return. European Journal of Marketing, 43 (5/6), 670685 .

Anthonisz, A. (2014). Assessing the future of housekeeping operations in Dubai's five-star hotel industry-room for innovation?. Worldwide Hospitality and Tourism Themes, 6 (4), 352-361.

Arbuckle, J. (2011). IMB SPSS AMOS 20 user's guide. Mount Pleasant, SC: AMOS development Corporation. Chicago, IL: SPSS Inc.

Barros, C. and Assaf, A. (2012). Analyzing tourism return intention to an urban destination. Journal of Hospitality \& Tourism Research, 36 (2), 216-231.

Barros, C., Butler, R. and Correia, A. (2010). The length of stay of golf tourism: A survival analysis. Tourism Management, 31 (1), 13-21.

Beesley, L. and Davidson, M. (2013). A critical analysis of skilled labor supply and demand in the Australian hospitality industry. Journal of Quality Assurance in Hospitality \& Tourism, 14, 264-280.

Benedict, G. and Stefan, S. (2004). Consumer Preferences for Mass Customization (No. 044).

Byrne, B. (2010). Structural equation modeling with AMOS: Basic concepts, applications, and programming. (2nd Ed.), Routledge, Taylor \& Francis Group publishing, New York.

Chahal, H. and Kumari, N. (2012). Consumer perceived value: the development of a multiple item scale in hospitals in the Indian context. International Journal of Pharmaceutical and Healthcare Marketing, 6 (2), 167-190.

Chen, H. (2012). The Influence of Perceived Value and Trust on Online Buying Intention. $J C P, 7$ (7), 1655-1662. 


\section{The Impact of Hotel Service Innovation on Guest's Perceived Value and Return Intention}

Chiang, C. and Jang, S. (2007). The effects of perceived price and brand image on value and purchase intention: Leisure travelers' attitudes toward online hotel booking. Journal of Hospitality \& Leisure Marketing, 15 (3), 49-69.

Chiang, C. and Lee, L. (2013). An examination of perceived value dimensions of hotel visitors: Using exploratory and confirmatory factor analyses. Journal of International Management Studies, 8 (1), 167-174.

Chuah, S., Marimuthu, M. and Ramayah, T. (2016). The Contribution of Perceived Firm Marketing Innovation Initiatives to Customer Perceived Value and Loyalty: Does Switching Experience Really Matter?. Asian Academy of Management Journal, 21 (1), 1-23.

Cronin, J., Brady, M. and Hult, G. (2000). Assessing the effects of quality, value, and customer satisfaction on consumer behavioral intentions in service environments. Journal of retailing, 76 (2), 193-218.

Dixon, M., Kimes, S. and Verma, R. (2009). Customer preferences for restaurant technology innovations. Cornell Hospitality Report, 9 (7), 6-16.

El-Adly, M. (2019). Modelling the relationship between hotel perceived value, customer satisfaction, and customer loyalty. Journal of Retailing and Consumer Services, 50, 322-332.

El-Adly, M. and Eid, R. (2015). Measuring the perceived value of malls in a nonWestern context: the case of the UAE. International Journal of Retail \& Distribution Management, 43 (9), 849-869.

Elston, R., Satagopan, J. and Sun, S. (Eds.). (2012). Statistical human genetics: Methods and protocols. New York, NY, USA: Humana Press.

Forozia, A., Zadeh, M. and Gilani, H. (2013). Customer Satisfaction in Hospitality Industry: Middle East Tourists at 3star Hotels in Malaysia. Research Journal of Applied Sciences, Engineering and Technology, 5 (17), 4329-4335.

Goh, Y. (2015). Investigating revisit intentions for the Boutique Hotels of Penang-A UNESCO world heritage site. Asian Social Science, 11 (4), 126.

Grobelna, A. and Marciszewska, B. (2013). Measurement of service quality in the hotel sector: The case of Northern Poland. Journal of Hospitality Marketing \& Management, 22, 313-332.

Hair, J., Black, C., Babin, B., and Anderson, R. (2010). Multivariate data analysis. (7th Ed.), Prentice Hall, Upper Saddle River, New Jersey. 
Hair, J., Black, W., Babin, B., Anderson, R. and Tatham, R. (2006). Multivariate data analysis. (6th Ed.). Uppersaddle River, N.J.: Pearson Prentice Hall

Han, H. (2013). The healthcare hotel: Distinctive attributes for international medical travelers. Tourism Management, 36, 257-268.

Hanai, T., Oguchi, T., Ando, K. and Yamaguchi, K. (2008). Important attributes of lodgings to gain repeat business: A comparison between individual travels and group travels. International Journal of Hospitality Management, 27 (2), 268 -275.

Hogan, S., Soutar, G., McColl-Kennedy, J. and Sweeney, C. (2011). Reconceptualizing professional service firm innovation capability: Scale development. Industrial Marketing Management, 40 (8), 1264-1273.

Hsu, L. and Lee, J. (2009). Empirical investigation of the roles of attitudes toward green behaviors, overall image, gender, and age in hotel customers eco-friendly decision-making process. International Journal of Hospitality Management, 28 (4), 519-528.

Hsu, Y. and Fang, W. (2009). Intellectual capital and new product development performance: The mediating role of organizational learning capability. Technological Forecasting and Social Change, 76 (5), 664-677.

Hu, L. and Bentler, P. (1999), Cutoff criteria for fit indexes in covariance structure analysis: conventional criteria versus new alternatives. Structural Equation Modeling a Multidisciplinary Journal, 6 (1), 1-55.

Kallmuenzer, A. (2018). Exploring drives of innovation in hospitality family firms. International Journal of Contemporary Hospitality Management, 30 (03), 19781995.

Kanten, S. and Yaşlioğlu, A. (2012). Role of Innovation in Creating Customer Value in Hotel Establishments: A Study On Managers. Süleyman Demirel Üniversitesi İktisadi ve İdari Bilimler Fakültesi Dergisi, 17 (2), 437-449.

Kessler, A., Pachucki, C., Stummer, K., Mair, M. and Binder, P. (2015). Types of organizational innovativeness and success in Austrian hotels. International Journal of Contemporary Hospitality Management, 27 (07), 1707-1727

Khuong, M. and Giang, T. (2014). The Effects of Service Innovation on Perceived Value and Guest's Return Intention: a study of luxury hotels in Ho Chi Minh City, Vietnam. International Journal of Trade, Economics and Finance, 5 (6), 503.

Kim, J., Kim, K., Garrett, T. and Jung, H. (2015). The contributions of firm innovativeness to customer value in purchasing behavior. Journal of Product Innovation Management, 32 (2), 201-213. 


\section{The Impact of Hotel Service Innovation on Guest's Perceived Value and Return Intention}

Komulainen, H., Mainela, T., Tähtinen, J. and Ulkuniemi, P. (2004). Exploring customer perceived value in a technology intensive service innovation. In Proceedings of the 20th Annual IMP-Conference, September (2-4).

Kotler, P. (2003). Marketing Management (11th ed.). Prentice-Hall, New York.

Kotler, P. and Keller, K. (2011). Marketing management (14th ed.). Upper Saddle River, NJ: Prentice-Hall.

Kozak, M. (2001). Repeaters' behavior at two distinct destinations. Annals of Tourism Research, 28 (3), 784-807.

Kozak, M. and Rimmington, M. (2000). Tourist satisfaction with Mallorca, Spain as an offseason holiday destination. Journal of Travel Research, 38 (3), 260-269.

Lien, C., Wen, M. and Wu, C. (2011). Investigating the relationships among eservice quality, perceived value, satisfaction, and behavioral intentions in Taiwanese online shopping. Asia Pacific Management Review, 16 (3), 211-22.

Lockyer,T. (2005). The perceived importance of price as one hotel selection dimension. Tourism Management, 26 (4), 529-537.

Lu, I. and Tseng, C. (2010). A study of service innovation activities of tourist hotels in Taiwan. The International Journal of Organizational Innovation, 03 (01), 156172.

Luoh, H., Tsaur, S. and Tang, Y. (2014). Empowering employees: Job standardization and innovative behavior. International Journal of Contemporary Hospitality Management, 26 (07), 1100-1117.

Lusch, R., Vargo, L. and O'Brien, M. (2007). Competing through service: Insights from service-dominant logic. Journal of retailing, 83 (1), 5-18.

Mahmoud, M., Hinson, R. and Anim, P. (2018). Service innovation and customer satisfaction: the role of customer value creation. European Journal of Innovation Management, 21 (3), 402-422.

Nagy, A. (2013). Approaching service innovation patterns. European Journal of Interdisciplinary Studies, 5 (1), 39-45.

Nieves, J. and Segarra-Ciprés, M. (2015). Management innovation in the hotel industry. Tourism Management, 46, 51-58. 
Nieves, J., Quintana, A. and Osorio, J. (2014). Knowledge-based resources and innovation in the hotel industry. International Journal of Hospitality Management, $38,65-73$.

Norazah, M. and Norbayah, M. (2015). Consumers' environmental behaviour towards staying at a green hotel: moderation of green hotel knowledge. Management of Environmental Quality, 26 (1), 103-117.

O'Cass, A., Song, M. and Yuan, L. (2013). Anatomy of service innovation: Introduction to the special issue. Journal of Business Research, 66 (1), 1060-1062.

Olaru, D., Purchase, S. and Peterson, N. (2008). From customer value to repurchase intentions and recommendations. Journal of Business \& Industrial Marketing, 23 (8), 554-565.

Ordanini, A. and Parasuraman, A. (2011). Service innovation viewed through a service-dominant logic lens: a conceptual framework and empirical analysis. Journal of Service Research, 14 (1), 3-23.

Palacios-Marques, D., Guijarro, M. and Carrilero, A. (2016). The use of customercentric philosophy in hotels to improve customer loyalty. Journal of Business \& Industrial Marketing, 31 (3), 339-348.

Parasuraman, A., Zeithaml, V. and Berry, L. (1988). Communication and control processes in the delivery of service quality. Journal of Marketing, 52 (2), 35-48.

Petrick, F. (2002). Development of a Multi-dimensional Scale for Measuring the Perceived Value of a Service. Journal of Leisure Research, 34 (2), 119-34

Prudon, P. (2015). Confirmatory factor analysis as a tool in research using questionnaires: A critique. Comprehensive Psychology, 4, 03-CP.

Rasoolimanesh, S., Dahalan, N. and Jaafar, M. (2016). Tourists' perceived value and satisfaction in a community-based homestay in the Lenggong Valley World Heritage Site. Journal of Hospitality and Tourism Management, 26, 72-81.

Razak, N., Marimuthu, M., Omar, A. and Mamat, M. (2014). Trust and repurchase intention on online tourism services among Malaysian consumers. Procedia-Social and Behavioral Sciences, 130, 577-582.

Ryu, K., Han, H. and Jang, S. (2010). Relationships among hedonic and utilitarian values, satisfaction and behavioral intentions in the fast-casual restaurant industry. International Journal of Contemporary Hospitality Management, 22 (3), 416-432.

Scholl-Grissemann, U. and Schnurr, B. (2016). Room with a view: how hedonic and utilitarian choice options of online travel agencies affect consumers' booking 


\section{The Impact of Hotel Service Innovation on Guest's Perceived Value and Return Intention}

intentions. International Journal of Culture, Tourism and Hospitality Research, 10 (4), 361-376.

Shanahan, K. and Hyman, M. (2007). An exploratory study of desired hotel attributes for American tourists vacationing in China and Ireland. Journal of Vacation Marketing, 13 (2), 107-118.

Stollery, A. and Jun, H. (2017). The antecedents of perceived value in the

Airbnb context. Asia Pacific Journal of Innovation and Entrepreneurship,11 (3), 391-404.

Sweeney, J. and Soutar, G. (2001). Consumer perceived value: The development of a multiple item scale. Journal of retailing, 77 (2), 203-220.

Tarka, P. (2018). An overview of structural equation modeling: its beginnings, historical development, usefulness and controversies in the social sciences. Quality \& quantity, 52 (1), 313-354.

Teng, C., Lu, A. and Huang, T. (2018). Drivers of consumers' behavioral intention toward green hotels. International Journal of Contemporary Hospitality Management, 30 (2), 1134-1151.

Thomas, R. and Wood, E. (2014). Innovation in tourism: Re-conceptualising and measuring the absorptive capacity of the hotel sector. Tourism Management, 45, 3948

Tigu, G., Iorgulescu, M. and Ravar, A. (2013). The impact of creativity and innovation in the hospitality industry on customers. Journal of Tourism Challenges and Trends, 06 (01), 09-34.

Toivonen, M. and Tuominen, T. (2009). Emergence of innovations in services. The Service Industries Journal, 29 (7), 887-902.

Um, S., Chon, K. and Ro, Y. (2006). Antecedents of revisit intention. Annals of Tourism Research, 33 (4), 1141-1158.

Wang, Y., Chen, S., Lee, Y. and Tsai, C. (2013). Developing green management standards for restaurants: An application of green supply chain management. International Journal of Hospitality Management, 34, 263-273.

Woodside, A. and MacDonald, R. (1994). General system framework of customer choice processes of tourism services. Spoilt for choice, 30.

Wu, C., Lin, C. and Lee, C. (2010). Competitive marketing strategies decisionmaking based on marketing resources and capabilities: Evidence from the hospitality 


\section{Ibrahim, Y $\quad$ M. Abbas, $T \quad$ S. Fahmy, N}

industry in Taiwan. Journal of Quality Assurance in Hospitality \& Tourism, 11, 219-238.

Zehrer, A., Muskat, B. and Muskat, M. (2015). Enablers of corporate innovation in tourism. In H. Pechlaner \& E. Innerhofer (Eds.), Competence-based innovation in hospitality and tourism (pp. in print). Farnham, Surrey, UK: Gower Publishing.

Zhou, Y. (2011). The impact of customer-based brand equity on revisit intentions: an empirical study of business and leisure travelers at five shanghai budget hotels. AU-GSB e-JOURNAL, 4 (1), 1906-3296.

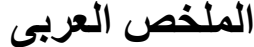 \\ تأثثر الابتكار فى الخدمات القندقية على القيمة المدركة للنزلاء والرغبة فى تكرار

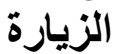

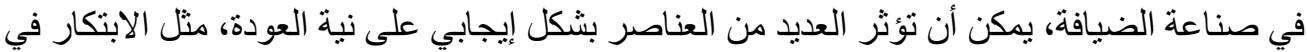

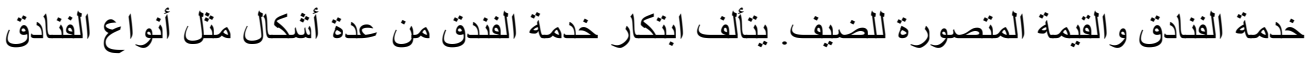

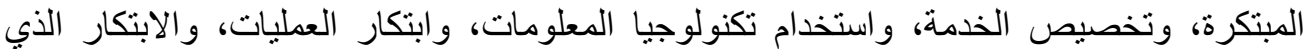

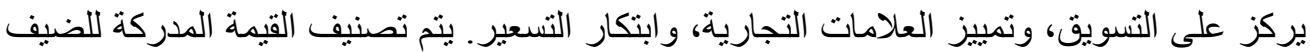

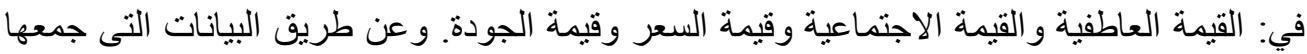

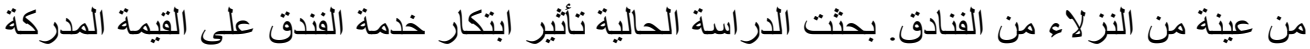

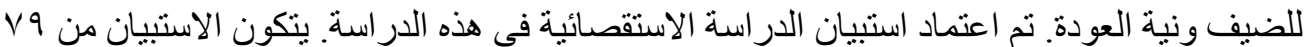

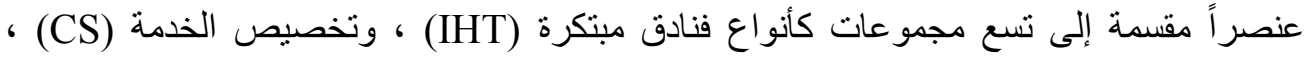

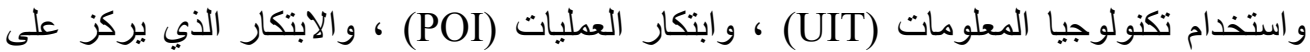

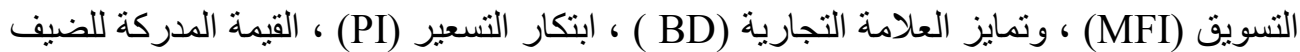

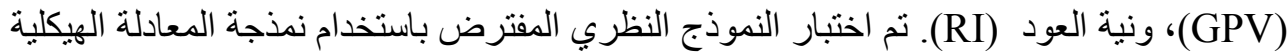
ككوبات (SEM)

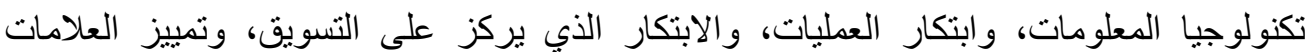

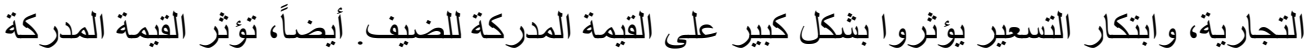

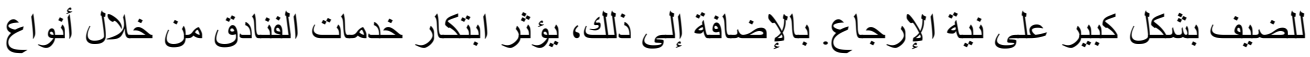
الفنادق المبتكرة بشكل كبير على نبة العودة. 